\title{
MEMBANGUN KOMPETENSI MANUSIA DALAM MILENIUM KE TIGA
}

\author{
Djamaludin Ancok \\ Universitas Isian indonesia
}

\begin{abstract}
Pada milenium ketiga tejadi pergeseran dalam paradigma kehidupan manusia, baik dari segi ekonomi maupun segi sosial dan psikologis. Pada milenium ketiga akan banyak perubahan yang disertai konflik antar manusia yang menuntut kemampuan adaptasi yang tinggi. Ada empa kapital yang harus dikembangkan sebagai kompetensi yang harus dimiliki oleh manusia untuk dapat beradaptasi secara sukses. Keempat kapital tersebut adalah kapital intelektual, kapital sosial, kapital lembut, dan kapital spinitual. Untuk membangun kapital tersebut diperlukan reorientasi penyelenggaraan pendididikan.
\end{abstract}

Kała kuncl : Milenium Ketiga, kompetensi, kapital intelektual, kapital sosial, kapital lembut, kapital spiritual.

Djamaludin Arcok, lahirdi Bangka, adalah Dekan Fakultas Psikologi Ull dan dosen Universitas Gadjiah Mada. Menyelesaikan program doktor psikologi sosial di Indlana Universily, USA.

\section{PENGANTAR}

alah satu ciri utama kehidupan di masa sekarang dan masa yang ada datang adalah cepatnya terjadi perubahan yang terjadi di dalam lingkungan kehidupan manusia. Banyak paradigma yang digunakan untuk menata kehidupan, baik kehidupan individual maupun kehidupan organisasi yang pada waktu yang lalu sudah mapan, kini menjadi ketinggalan zaman. Akhis-akhir ini banyak sekali muncul tulisan tentang pergeseran paradigma kehidupan. Umumnya tulisan tersebut menganalisis tentang paradigma baru yang perlu diterapkan untuk memasuki milenium ketiga. Tulisan tersebut terfokus pada perubahan paradigma yang membedakan milenium ke dua dan milenium ketiga.

Salah satu pergeseran paradigma adalah paradigma di dalam melihat apakah kondisi kehidupan di masa depan relatif stabil dan bisa diramalkan (predictability). 
Pada mille nium kedua orang selalu berfikir bahwa segala sesuatu bersifat stabil dan bisa diprediksi. Pada milenium ketiga semakin sulit untuk melihat adanya stabilitas tersebut. Apa yang terjadi of depan semakin sulit untuk diprediksi karena perubahan menjadi tidak terpolakan dan tidak lagi bersifat linier. Banyak contoh yang bisa dikernukakan untuk mendukung pendapat tersebut. Bila pada awal tahun sernbilan puluhan (akhir mileniurn kedua) para pakar memprediksi bahwa Asia akan menjadi pusat perdagangan dunia karena jumlah penduduk yang besar sebagai pasar, dan pertumbuhan ekonomi yang tinggi di atas $7 \%$ (lihat Naisbitt, 1995), tanpa diduga di penghujung dekade akhir millenium ketiga, ekonomi berbagai negara Asia jatuh tersungkur dengan tingkat pertumbuhan ekonomi yang mendekati nol atau minus. Tidak ada orang yang menduga bahwa perturnbuhan ekonomi negara tersebut begitu mengenaskan. Contoh lainnya adalah kondisi di negara kita sendiri, yakni kuatnya pernerintahan yang dipimpin oleh rezirn Suharto. Tidak ada dugaan kalau rezim Suharto akan berakhir tragis dengan meninggalkan beban malapetaka yang maha berat menimpa rakyat Indonesia. Berbagai krisis moneter yang melanda Korea, Thailand, Filipina, Malaysia, Indonesia dan berbagai negara Asia lainnya, serfa runtuhnnya rezim Suharfo yang tanpa diduga adalah bukti bahwa paradigma stabilitas dan prediktabilitas sudah harus ditinggalkan.

Untuk menghadapi kondisi of milenium ketiga yang semakin tidak bisa diprediksi tersebut, diperlukan perubahan di dalarn sikap mental manusia. Orang tidak bisa lagi bersifat reaktif, menunggu dan menghindari resiko demi memperfahankan status-quo. Orang harus bersifat proaktif dan merniliki toleransi atas ketidakjelasan yang terjadi akibat perubahan dengan tingkat turbulensi yang tinggi. Banyak pakar yang melihat kegagalan manusia, knususnya kegagalan di dalam berbisnis dan mengelola negara karena sifat yang tidak proaktif dan melihat sukses masa lalu sebagai suatu jaminan sukses of masa depan. Sukses di masa ialu tidak akan menjarnin sukses di masa depan, karena masa depan akan sangat berbeda dengan masa lalu. Orang harus terus mernpertanyakan formula sukses masa lalu apakah masih bisa ditorapkan unituk kondisi perubahan yang super cepat. Blia tidak dilihat dengan kritis formula sukses di masa lalu akan menjadi sumber kegagalan d masa depan (lihat Gibson, 1997. hal 6-7).

\section{PARADIGMA EKONOMI BARU}

Kemajuan teknologi komputer telah menyebabkan perubahan yang sangat mendasar di dalarn tata kehidupan manusia. Teknologi komputer telah mengubah pola hubungan manusia. Manusia semakin terbebaskan dari ikatan ruang dan waktu. Kehadiran internet telah mendekatkan hubungan antar manusia di seluruh dunia yang merniliki teknologi canggih tersebut. Kini manusia hidup dalam salu jejaringan informasi yang cerdas (networked intellgence). Don Tapscott (1998) dalam buku best seller yang berjudul' Digital Economy: Promise and Peril in the Age of Networked Intelligence' mengemukakan 12 paradigrna baru dari kehidupan ekonorni yang akan menjadi ciri millenium ketiga. Beberapa dari paradigma baru tersebut akan dibicarakan berikut ini.

\section{Ekonoml Baru Merupakan Ekonoml Pe- ngetahuan (knowledge based economy).}

Pada era industriliasasi teriadi pergeseran pola kerja dari yang berfokus pada kerja otot (brawn) menuju pola kerja yang menekankan pada penggunaan otak 
(brain). Produk berkembang ke arah produk yang pintar (smart product), misalnya kartu pintar (smart card). Bila saat ini orangmemiliki berbagai kartu dalam dompet (misal kartu penduduk, SIM, kartu kredit, kartu tunai, kartu diskon, dil.), pada milenium ketiga kartu yang begitu banyak macamnya akan terwakili oleh satu kartu saja yang bisa melayani berbagai penggunaan seperti SIM, KTP, kartu Kredit, paspor, kartu asuransi, kunci rumah, kunci mobil, dll.

Rumah masa depan adalah rumah yang cerdik (smart house) yang dilengkapi komputer yang $\mathrm{mampu}_{\mathrm{a}} \mathrm{memberi} \mathrm{informasi}$ tentang kondisi di rumah, misalnya apakah kompor masih hidup karena lupa dimatikan, binatang peliharaan apakah sudah diberi makan, semua pintu apakah sudah dikunci. Kalau ada hal-hal yang demikian, maka rumah bisa diperinfahkan melalui internet untuk melakukan tugas-tugas yang belum terselesaikan. Binatang dapat memperoleh makanannya secara otomatis bila induk sernangnya lupa memberi makan. Rumah bisa mengatur suhu ruangan sesuai keperIuan. Bila anak-anak ditinggalkan d rumah. orang tua bisa melihat keadaan anak-anak di rumah melalui internet.

Mobil masa depan adalah mobil yang cerdik. Mobil tidak mau bergerak bila pengendaranya dalam keadaan mabuk. Mobil akan nemberi informasi kondisi lalu lintas di jalan yang dilalui. Mobil juga akan bisa memberi informasi tentang kerusakan yang terjadi pada mobil melalui alat perekam informasi yang dioperasikan komputer.

Banyak produk lain yang memiliki kecerdikan seperti kecerdikan yang ada pada kartu, rumah, dan mobil yang diceritakan di atas, misalnya televisi yang bisa diajak berdialog, jalan raya yang bisa memberitahu kondisi Jalan, ban mobil yang bisa menyesuaikan tegangan angin yang diperlukan, dil.

\section{Ekonoml baru adalah ekonomi yang vir- tual (virtualization)}

Kehadiran komputer yang beroperasi dengan sistem digital telah membebaskan manusia dari ikatan ruang dan waktu. Orang bisa berkomunikasi dengan orang lain di seluruh penjuru dunia dengan bantuan komputer yang memiliki jalur telepon dan modern. Kondisi demikian ini mengubah cara kerja manusi dan cara keria organisasi. Karyawan sebuah perusahaan tidak selalu perlu pergi ke kantor karena banyak pekejaan yang dapal dikerjakan di mumah dan dikirim hasilnya lewat internet. Sekretaris bisa menghubungi bos dan mengirim suraf dan dokumen dari mana saja. Kantor tidak lagi memerlukan gedung yang tetap. Kantor suatu pensahaan bisa ada di manamana karena fungsinya telah diganti oleh komputer. Relasi bisnis dan karyawan dapat menghubungi dan dihubungi setiap saat di mana saja. Keadaan yang demikian menyebabkan karyawan suatu perusahaan bisa tersebar d berbagai negara, karena hubungan kerja mereka cukup melajui komputer.

Banyak kantor bank konvensional di perbagai penjuru dunia merasa terancam dengan kehadiran 'virtual bank' karena pekerjaan perbankan digantikan oleh komputer. Bank virtual tidak memerlukan karyawan yang banyak, tidak memerlukan gedung yang besar, tidak menghabiskan biaya alat tulis, tidak memerlukan ruangan parkir bagi karyawan. Semua kondisi ini akan membuat biaya operasi bank menjadi sangat kecil, dan daya saingnya meningkat.

Virtualisasi ini akan melanda Iembaga pendidikan. Para mahasiswa tidak perlu lagi datang ke kampus. Mereka bisa belajar dari mana saja di seluruh dunia melalui 'tele-conference' dan internet. Mungkin pada masa awal penerapan sistem ini dipertukan biaya yang besar untuk mema-

PSIKOLOGIKANomor GT ahun H11998 
sang fasilitas virtual tersebut. Namun untuk jangka panjang biaya operasi perguruan tinggi akan lebih murah karena tidak diperlukan lagi gedung yang besar, dosen yang banyak, dan tenaga administrasi yang banyak.

Kini orang yang berbelanja tidak perlu lagi datang ke supermarket, atau ke toko. Orang berbelanja melalui internet. Produk yang akan dijual dapat dilihat bentuk, wama, karakteristik, dan harganya melalui tampilan televisi. Pembeli cukup memesan barang dan membayarnya dengan kartu kredit melalui internet.

\section{Ekonomi baru merupakan ekonomi inovasi}

Kini berbagai produk keperluan manusia mudah sekali ketinggalan zaman. Siklus kehidupan produk (product life cycte) semakin pendek. Suatu perusahaan yang menghasilkan produk dan jasa harus inovatif bila ingin 'survive' dalam bisnis. Produk harus bersifat unik agar memenuhi selera manusia yang semakin ingin tampil beda.

Inovasi melanda seluruh kehidupan sosial dan ekonomi. Perpustakaan berubah dalam disket, atau dalam compact disk. Sebuah compact disk bisa menyimpan 360.000 halaman teks. Penelusuran literatur akan sangat cepat karena informasi sudah dikategorikan secara sistimatik. Untuk mendengarkan musik seseorang tidak harus membeli tape-recorder dan kaset karena komputer telah memiliki fasilitas multi media yang bisa mengganti fungsi tape recorder. Orang tidak perlu lagi membeli laser disk dan televisi, atau pergi ke gedung bioskop untuk menonton film, karena film bisa ditonton melafui internet. dan bisa ditonton di mana saja selama handphone masih bisa menangkap sinyal.

Munculnya berbagai produk ban akibat inovasi yang terus menerus, membuat manusia terpacu untuk membeli dan memitiki produk baru. Ramainya promosi produk baru melalui berbagai media membuat masyarakat berubah menjadi manusia yang suka membuang barang. Barang yang modelnya sudah ketinggalan diganti dengan produk dengan model baru. Alvin Toffler dalam buku Future Schock ( 1970 ) menamakan masyarakat yang memiliki sifat demikian dengan throw away society.

\section{Ekonomi baru ekonomi yang melibatkan konsumen dalam perancangan produk dan Jasa}

Peranan konsumen tidak hanya dalam hal membeli dan menggunakan produk dan jasa. Di masa depan keterlibatan konsumen di dalam merancang produk dan jasa akan semakin besar. Seorang pembeli rumah yang dibuat oleh pengusaha 'real-estate' semakin tidak tertarik untuk membeli rumah yang sudah jadi. Pembeli mau terlibat d dalam merancang rumah yang akan dibelinya. Kini semakin banyak pengusaha realestate of negara maju yang menyediakan fasilitas komputer untuk merancang rumah dengan membiarkan pembeli untuk memilih bentuk rumah (pintu, jendela, kamar mandi, pembagian ruangan). Berbagai jenis gambar komponen rumah dimasukkan ke dalam komputer. Pembeli akan merancang sendin rumah yang akan dibangunnya dengan mengkombinasikan komponen tersebut. Setelah gambar rumah dibuat, komputer akan sekaligus memberi tahu berapa biaya membuatnya, dan berapa lama waktu yang digunakan untuk menyelesaikannya.

Di bidang jasa pelayanan pun konsumen semakin ingin terlibat di dalam menentukan jenis layanan yang akan diperolehnya. Misalnya pasien di rumah sakit ingin teribat df dalam menentukan jenis terapi yang akan dijalaninya. Dokter yang tidak melibatkan pasien di dalam menentukan jenis 
terapl akan ditinggalka n oteh pasien. Dokter yang seperti ini akan menjadi dokter yang tidak laku prakteknya.

\section{Ekonoml baru adalath ekonoml yang salling tergantung (integration/internetworking)}

Bila pada milenium kedua organisasi bisnis dan negara berfokus untuk membangun kemandirian, kini paradigma tersebut sudah ditinggalkan. Organisasi bisnis, atau organisasi apapun (termasuk negara) tidak bisa menghindari ketergantungan dengan pihak lain. Pada level bawah apa yang d:lakukan suatu lembaga bisnis akan menpengaruhi bisnis yang lain. Apa yang terjadi di suatu negara akan mempengaruhi kehidupan di negara lain. Misalnya menguatnya nilai dollar atas mata uang negara lain. membuat ekonomi berbagai negara di Asia menjadi sulit.

Dalan kondisi ekonomi yang demikian. akan lebih menguntungkan dan akan lebih menjamin keberlangsungan hidup organisasi, bila bebagai pihak melakukan kerja sama yang saling menguntungkan dalam suatu aliansi strategik (strategic alliances).

\section{Masyarakat ekonom! baru akan penuh dengan konflik (discordance)}

Kondisi ekonomi baru seperti yang digambarkan dalam berbagai paradigma ekonomi di atas akan menimbulkan banyak masalah sosial dan psikologis. Perubahan paradigma dari yang lama ke yang baru akan menimbulkan berbagai goncangan sosial dan psikologis yang memerlukan upaya untuk menanganinya.

Dalam kondisi ekonomi yang sangat diatur oteh sistem informasi teknologi yang canggih, masyarakat yang unggullah yang akan memetik keuntungan yang besar. Masyarakat yang berpendidikan rendah, secara ekonomi lemah, dan tidak memiliki akses kekuasaan akan ketinggalan jauh. Kondisi demikian akan menumbuhkan masalah sosial dan psikologis. Kesenjangan ekonomi antara golongan atas dan golongan bawah semakin melebar. Untuk terlibat dalan ekonomi baru diperlukan manusia yang memiliki pengetahuan yang luas (knowledge workers). Mereka yang tidak memiliki pengetahuan yang cukup akan tidak bisa memasuki pasaran kerja. Berbagai bentuk patologi sosial akan semakin tinggi kualitas dan kuantitasnya. Pengangguran akan semakin meningkat, yang selanjutnya akan diikuti oleh meningkatnya angka kriminalitas. Ketegangan karena kesenjangan sosial yang melebar ini dapat mengambil bentuk mudahnya masyarakat terlibat dalan kerusuhan sosial. Ketegangan emosi yang amat tinggi akan menyebabkan manusia dengan mudah mengakhiri hidupnya dengan bunuh diri.

Potensi konflik tersebut akan semakin kuat nuansanya, karena masyarakat d mitenium ketiga masih membawa permasalahan yang belum terselesaikan of milenium kedua. Berbagai masalah di milenium kedua yang belum terselesaikan antara lain adalah masalah kependudukan dan masalah lingkungan hidup (Kennedy, 1993). Bila diterapkan pada kondisi Indonesia apa yang dikatakan Kennedy tersebut sangat menguatirkan. Penduduk Indonesla di awal tahun 2000 sudah berjumlah sekitar 208 juta orang. Kondisi ekonomi yang moratmarit saat ini akan berhadapan dengan kedatangan angkatan kerja baru dalam jumlah besar. Dalam kondisi ekonomi yang normal sekalipun indonesia akan menghadapi masalah besar dalam penyediaan tenaga kerja. Dalam kondisi ekonomi yang sulit ini, masalah semakin parah, karena angkatan kerja yang adapun semakin banyak yang kehilangan pekerjaannya karena pernutusan hubungan kerja. 
Dari sisi lingkungan hidup kita melihat banyak terjadi kerusakan lingkungan. Bahan tambang sudah semakin menyusut. Proses penggundulan hutan terjadi dengan kecepatan yang tinggi akibat hutan-hutan tropis ditebang oleh para konglomerat yang kurang memikirkan kelestariannya. Perkotaan semakin sesak oleh manusia karena proses urbanisasi. Polusi udara masih merupakan masalah besar yang sangat mengganggu keseimbangan ekosistem. Semua ini akan menimbulkan permasalahan daya dukung lingkungan terhadap manusia. Alam semakin sering marah pada manusia karena ekosistem yang dirusak oleh manusia. Menipis dan bocornya lapisan ozon telah mengacaukan keteraturan siklus alam. Belum begitu lama kita mengalami akibat EI-Nino yang membuat cuaca yang sangat panas di Indonesia dan memacu kebakaran hutan; kini indonesia akan dihadapkan pada masalah baru La-Nina yang diduga akan mendatangkan banjir yáng melanda pantai utara Jawa dan pantai yang tingkat elevasinya rendah d berbagai kepulauan Indonesia.

\section{MANUSIA MILENIUM KETIGA YAMG PERLU DIPERSIAPKAN}

Milenium ketiga adalah masa yang memberikan banyak peluang dan sekaligus banyak tantangan yang menyulitkan. Kesuksesan merebut peluang dan menghindari kendala semuanya terpulang pada kemampuan manusia untuk mengelola peluang dan tantangan. Untuk menghadapi hal tersebut tiada lain kecuali manusia harus menghadapinya secara bersama-sama dengan memiliki visi misi, dan value yang sama.

Maynard dan Mehrtens (1993) beranggapan milenium ketiga adalah kelanjutan tahap perubahan dunia yang digambarkan oleh Alvin Toffler dalam buku The
Power Shift (1990). Alvin Toffierteranggapan bahwa perubahan dunia terjadi dalam tahapan yang berbeda mulai dari gelombang pertama (First Wave), gelombang kedua (Second Wave), dan gelombang ketiga (Third Wave). Maynard dan Mehrtens (1993) menamakan millelium ketiga sebagai gelombang keempat (Fourth Wave) dari perkembangan dunia.

Gelombang Pertama (First Wave) adalah era pertanian, yang berfokus pada kehidupan yang bergelut dengan alam. Hubungan manusia dengan alam lebih tertuju pada perlakuan individual terhadap alam, dan manusia lebih dikuasai oleh alam dari pada dia menguasai alam. Pada masa ini manusia bisa hidup sendiri-sendiri untuk mencarf kehidupan. Peranan otot (brawn) akan lebih besar dari peranan otak (brain) di dalam kelangsungan hidup manusia. Pekerjaan manusia di era pertanian lebih didominasi oleh kerja otot mengolah alam daripada kerja otak. Pada era pertanian kerjasama antar manusia tidak terlalu urgen untuk keberlangsungan hidup. Pada masa ini nuansa kompetisi antar manusia sangat lemah atau hampir tidak ada kompetisi.

Gelombang Kedua (Second Wave) adalah era industrialisasi. Manusia semakin menggunakan akalnya untuk menciptakan mesin guna mepermudah kehidupan manusia. Pada masa ini diciptakan mesin uap. pembangkit tenaga listrik, alat-alat transportasi yang menggunakan mesin. Irama hidup manusia semakin cepat karena adanya alat transportasi dan alat komunikasi yang semakin canggih. Pada masa ini nuansa kompetisi antar manusia semakin mengental. Manusia berkompetisi untuk menguasai sumberdaya alam. Persaingan menuntut mereka untuk unggul dan mandiri. Dalam masa ini ada kecenderungan kuat untuk melihat pihak lain sebagai kompetitor. Masa ini ditandai dengan suatu pola permainan zero-sum game. Saya menang 
kamu kalah, atau sebaliknya kamu menang saya kalah. Pada era ini nuansa keserakahan manusia untuk menguasai sumberdaya sangat menonjol.

Gelombang Ketiga (Third Wave) adalah era informasi. Ini adalah bagian penting dari awal milenium ketiga. Pada era ini manusia memanfaatkan informasi sebagai kekuatan dalam kehidupan. Teknologi komputer menjadi penguasa. Hampir semua pekerjaan sudah bisa diatur oleh komputer, dan banyak pekerjaan dilakukan oleh robot yang diprogram oleh komputer. Pada era ini manusia saling terkait satu dengan lainnya dan mereka harus bekerja sama. Era ini ditandai dengan keterkaitan manusia melalui intemet. Manusia menghadapi peluang untuk belajar yang sangat besar karena mereka bisa memanfaatkan internet sebagai sarana urituk memperluas pengetahuan mereka. Kemampuan belajar untuk meperluas pengetahuan akan menjadi faktor survival. Pada masa ini masyarakat harus membangun 'learning soclety. Pada era ini manusia saling terkait dan harus saling bekerjasama untuk berbagi wawasan guna memperoleh keuntungan bersama,

Gelombang keempat (Fourth Wave) adalah era yang ditandai oleh semakin intensifnya pemanfaatan teknologi komputer, dan semakin canggihnya perangka! teknologi informasi. Nuansa perubahan pada gelombang ketiga yang menekankan pada kerjasama ternyata tidak cukup kuat untuk menangkal dampak negatif yang muncul dari era gelombang ketiga. Pada era gelombang keempat ini manusia harus membangun tata-nilai baru. Manusia di berbagai negara akan survive bila mereka dapat melihat dirinya dalam suatu kesatuan. Manusia harus menjadi pelayan dunia (serve as a global steward), harus memiliki visi, misi, dan values yang sama untuk menjaga kelangsungan hidup alam semesta, termasuk kehidupan bersama umat manusia.

Hidup pada era gelombang keempat tidak lagi hanya terfokus pada kelangsungan hidup manusia, tetapi juga kelangsungan hidup alam yang berfungsi sebagai penyangga kehidupan manusia. Fokus perhatian dalam kegiatan pembangunan harus berorientasi pada kelangsungan hidup di masa depan. Strategi kelangsungan di gelombang keempat ini sangat sesuai dengan ajaran agama yang memerintahkan manusia untuk menjaga alam semesta ini. Manusia harus melihat dirinya sebagai ummat yang satu (ummataw-wahidah) sebagai kalifafulah fil-ard yang harus memelihara alam semesta, dan secara bersama-sama berbuat untuk kepentingan bersama. Maynard dan Mehrtens (1993) menggambarkan kondisi tersebut dalam suatu paradigma kehidupan baru berorientasi pada we are one and choose bo $\infty$ create.

Pada era gelombang keempat ini kita harus semakin menyadari pentingnya penghargaan terhadap keanekaragaman (diversity). Mengambil contoh kehidupan biologis, suatu tanaman yang hanya terdiri atas satu jenis tanaman saja akan mudah sekali diserang oleh penyakit. Keunggulan suatu spesies tanaman sangat tergantung pada dukungan dari berbagai jenis tanaman lainnya (bio-diversity). Indonesia pernah mengalami kegagalan panen padi karena diserang oleh hama wereng. Dengan secara bergantian menanam padi dan palawija, serangan hama wereng bisa diatasi. Keadaan yang sama juga berlaku pada manusia.

Kelangsungan hidup bermasyarakat dan bisnis sangat tergantung pada pengakuan dan penghargaan pada keanekaragaman tersebut (lihat Moore, 1996). Moore mengatakan suatu organisasi bisnis akan berusia panjang bila dia memperhatikan 
ekosistem bisnis yang beraneka ragam, dan membangun sinergi dengan berbagai organisasi yang merupakan komponen ekosistem tersebut.

Tidak ada komponen kehidupan dalam masyarakat yang tidak memberi peluang untuk kemajuan bersama. Pendiri negara indonesia sudah sangat menyadari betapa pentingnya menghargai dan memanfaatkan perbedaan tersebut seperti yang termuat dalam lambang negara Bhinneka Tunggal ka. Pengalaman menunjukkan bahwa bila kekuatan politik hanya muncul dari kekuatan 'single majority yang tidak memperhatikan aspirasi kelompok yang beraneka ragam dengan memaksakan ideologi yang dianggapnya paling benar maka hancurlah suatu negara yang dikuasai oleh 'singlemajority.

Kekacauan antaretnik yang mengganggu keamanan masyarakat tejiadi karena kurangnya perhargaan antar etnik yang menjadi komponen bangsa. Peristiwa kenusuhan etnis yang terjadi di Los Angeles yang sangat merugikan banyak pihak karena keberpihakan pemerintah pada satu kelompok etnik tertentu (lihat Jarman \& Land, 1995). Semua ini mengingatkan kepada kita betapa benarnya ajaran islam. Bahwa perbedaan yang diikat dengan rasa saling menghargai dan tidak saling menguasai akan mendatangkan kekuatan.

Konsep keanekaragaman sangat sesusai dengan perintah agama. islam mengajarkan kita untuk menghargai perbedaan, karena perbedaan itu adalah hikmah bagi mereka yang mengerti.

\section{PERANAN PENDIDIKAN TINGGI DI DALAM MENYIAPKAN MANUSIA MILENIUM KETIGA}

Lembaga pendidikan tinggi mengemban berbagai tugas, tugas pendidikan dan pengajaran, tugas penelitian dan pengem- bangan ilmu, serta tugas pengabdian pada masyarakat. Tugas-tugas ini terlembagakan dalarn Tri Dharma Perguruan Tinggi. Adanya dharma ke tiga di bidang pengabdian masyarakat menempatkan lembaga pendidikan tinggi sebagai suatu garda moral bagi bangsa dan negara.

Sebagai lembaga pendidikan, perguruan tinggi harus dapat menyiapkan manusia yang memiliki kompetensi untuk hidup bersama dalam ikatan global. Lembaga pendidikan harus dapat mengembangkan kapital yang diperlukan untuk memasuki kehidupan milenium ketiga. Ada empat jenis kapital yang diperlukan untuk memasuki milenium ketiga, yakni kapital intelektual, kapital sosial, kapital lembut, dan kapital spirilual (Hartanto, 1997; Hartanto, Paka \& Hendroyuwono, 1998). Dengan menumbuhkan manusia dengan keempat kapital ini diharapkan akan terwujud manusia yang berorientasi 'Kita' bukan berorientasi "Saya" (diri saya, keluarga saya, golongan saya, partai saya, fakultas saya, jurusan saya). Manusia yang dernikian inilah yang disebut oleh Stephen Covey sebagai manusia yang effektif (Covey, 1989).

\section{Kapital Intelektual}

Kapital intelektual adalah perangkat yang diperlukan untuk menemukaan peluang dan mengelola ancaman dalarn kehidupan. Banyak pakar yang mengatakan bahwa kapital intelektual sangat besar peranannya di dalam menambah nilai sualu kegiatan. Bertagai perusahaan yang unggul dan meraih banyak keuntungan adalah perusahaan yang terus menerus mengembangkan sumberdaya manusianya (lihat Ross, dkk, 1997).

Manusia harus memiliki sifat proaktif dan inovatif untuk mengelola perubahan lingkungan kehidupan (ekonomi, sosial, politik, teknologi, hukum dil) yang sangat 
tinggi kecepatannya. Mereka yang tidak beradaptasi pada perubahan yang super cepat ini akan dilanda kesulitan. Pada saat ini manusia, organisasi, atau negara tidak lagi berlayar di sungai yang tenang yang segala sesuatunya bisa diprediksi dengan tepat. Kini sungai yang dilayari adalah sebuah arung jeram yang ketidakpastian jalannya perahu semakin tidak bisa diprediksi karena begitu banyaknya rintangan yang tidak terduga. Dalam kondisi yang ditandai oleh perubahan yang super cepat manusia harus terus mempertuas dan mempertajam pengetahuannya dan mengembangkaan kretivitasnya untuk berinovasi.

Perguruan tinggi sebagai garda paling depan d dalam mengembangkan kapital intelektual harus mampu membangun suatu masyarakat pengetahuan (knowledge community). Hal ini baru terjadi bila seluruh jajaran pengelola perguruan tinggi berusaha secara serius untuk menanamkan kesadaran guna menambah pengetahuan baik pada dirinya sendiri, atau pada mahasiswa yang diasuhnya. Para dosen tidak boleh puas dengan apa yang sudah dicapainya secara akademik.

Pekerjaaan membangun kapital intelektual adalah pekerjaan yang tiada akhir, karena ilmu yang kita miliki akan mudah sekali ketinggalan zaman. Kita akan menjadi penyebar kerusakan bila konsep yang kita ajarkan adalah konsep yang sudah tidak sesuai dengan tuntutan perubahan. Untuk mengatasi hal-hal yang demikian suasana akademik di kampus harus ditumbuhkan melalui berbagai forum akademik, antara lain seminar ilmiah, colloquium, diskusi pembahasan buku baru, harus menjadi kebiasaan sehari-hari di kampus. Dengan melakukan saling tukar informasi dan wawasan yang melibatkan dosen dan mahasiswa melalui forum tersebut akan semakin berkembang kapital intelektual. Apa yang disarankan para pakar tersebut sud ah jauh- jauh hari ditulis dalam kitab suci.

Al-Quran mewajibkan setiap manusia untuk banyak membaca guna mengembangkan kapital intelektualnya. Ayat alQuran yang pertama kali turun adalah perintah untuk membaca: Bacalah dengan (menyebut) nama Tuhanmu yang menciptakan. (Al-Alaq ayat 1). Banyak ayatayat al-Quran lainnya yang senada, misalnya dalam surat Ali imran, ayat ke 190191 Allah berfirman:

Sesungguhnya datem penciptaan langit den bumi, dan sith bergantinya malam dan siang terdapat tanda-tanda bagi orang yang berakal, (yaitul orang-orang yang mengingat Allah sambil berdiri atau duduk atau dalam keadaan ber. baring dan mereka memikirkan tentang penciptaan langit dan buml (seraya berkata). "Va Tuhan kami, tiadalah Engkau menciptakan int dengan sia-sia, Maha Sucl Engkau, maka peliharalah kami dari siksa neraka".

\section{Kapita! Soslal}

intelektual kapital baru akan tumbuh bila masing-masing orang berbagi wawasan. Untuk dapat berbagi wawasan orang harus membangun jaringan hubungan sosial dengan orang lainnya. Kemampuan membangun jaringan sosial inilah yang disebut dengan kapital sosial. Semakin luas pergaulan seseorang dan semakin luas jaringan hubungan sosial (social networking) semakin tinggi nilai seseorang.

Kapital sosial dimanifestasikan pula dalam kemampuan untuk bisa hidup dalam perbedaan dan menghargai perbedaan (diversity). Pengakuan dan penghargaan atas perbedaan adalah suatu syarat tumbuhnya kreativitas dan sinergi. Kemampuan bergaul dengan orang yang berbeda, dan menghargai dan memanfaatkan secara bersama perbedaan tersebut akan memberikan ke- 
baikan buat semua. Dalam ajaran Islam setiap manusia diminta membangun silaturahmi. Karena silaturahmi akan memberikan kebaikan. Ide kreatif seringkali muncul melalui diskusi. Demikian pula peluang bisnis seringkali terbuka karena adanya jaringan hubungan silaturahmi.

Perintah tentang membangun kapital sosia! ini sangat dianjurkan oleh agama seperti yang difirmankan oleh Allah dalam al-Quran berikut ini:

Hai manusia, sesungguhnya Kami menciptakan kamu dari seorang laki-laki dan seorang perempuan dan menjadjkan kamu berbangsa-bangsa dan bersuku-suku supaya kamu kenal mengenal (Ail Hujerat, ayat 13).

Untuk menumbuhkan kapital sosial pada manusia kampus dan di luar kampus diperlukan kegiatan pengabdian masyarakat. Banyak pelatihan yang bisa ditawarkan pada masyarakat kampus dan luar kampus untuk menumbuhkan kapital sosial. Misalnya pelatihan untuk menumbuhkan 'social skil?, pelatihan untuk menjadi manusia efektif seperti paket Seven Habits of Highly Effective People yang sekarang ini sangat pupuler di berbagai negara. Berbagal ilmu d bidang hubungan antar manusia (human relations) telah memberikan jalan bagaimana manusia harus berinteraksi dalam suatu kebersamaan yang saing menguntungkan.

\section{Kapitai 'Lembut' (soft capitan}

Kapital lembut yang oleh Hartanto (1998) disebut dengan "soft capital" adalah kapital yang diperlukan untuk menumbuhkan kapital sosial dan kapital intelektual. Sifat bisa dipercaya dan pencaya pada orang lain (trust), bisa menahan emosi, pemaaf, penyabar, ikhlas, dan selalu ingin menyenangkan orang lain sangat diperlukan bagi upaya untuk membangun masyarakat yang beradab dan berkinerja tinggi.

Berdasarkan analisis terdahulu ekonomi baru di milenium ketiga akan diwamai oleh banyaknya konflik yang terjadi (discordance). Orang semakin tidak bisa melihat orang lain sebagai bagian dari sukses dirinya sendiri. Konflik antar kelompok kaya dan miskin, kelompok berpengetahuan tinggi dan berpengetahuan rendah, kelompok yang memiliki akses pada kekuasaan dan yang tidak memiliki akses pada kekuasaan diduga akan meningkat intensitasnya. Soft capital ini akan menjadi perekat sosial dan peredam emosi yang dapat menekan munculnya konflik dan kekerasan.

Islam sangat menyarankan manusia untuk mengembangkan soft capital. Banyak ajaran agama yang ditulis dalam Quran dan hadist agar manusia memiliki sifat yang demikian. Salah satu ayat dalam al-Quran yang menggambarkan ciri orang yang takwa dan menjadi penghuni surga adalah seperti berikut:

Dan bersegeralah kamu kepada ampunan dari Tuhanmu dan kepada syurga yang luasnya seluas langit dan bumi yang disediakan untuk orang-orang yang bertakwa, (yaitu) orang-orang yang menafkahkan (hartanya), baik d wakkilapangmaupunsempit, can orangorang yang menahan amarahnya dan memaafkan (kesalahan) orang. Allah menyukai orang yang berbuat kebajikan. (Ali Imran, ayat 133-134)

Beberapa tahun terakhir ini makin banyak pembicaraan tentang pentingnya peranan inteligensi emosional (emotional intelligence) di dalam menunjang kesuksesan hidup manusia (Goleman, 1996). Apa yang ditulis oleh Daniel Goleman tersebut sangat sesuai dengan ajaran agama.

Upaya untuk menumbuhkan kapital lembut ini bisa melalui pengajian agama, 
pelatihan 'social skill', pelatihan inteligensi emosisonal, atau paket Seven Habits of Highly Effective People. Sudah saatnya lembaga pendidikan tinggi mewajibkan mahasiswanya untuk mengikuti paket pengembangan kepribadian seperti itu. Karena sifatnya sangat praktis dan segera terasa manfaatnya Insya Allah kegiatan ini akan sangat menarik, dan jauh lebih berguna dibandingkan penataran P-4 yang sarat dengan muatan politik yang mendukung kekuasaan penguasa.

\section{Kapital Spiritua!}

Bagi orang Islam ketiga kapital yang dibicarakan di atas adalah bagian dari ekspresi kapital spiritual. Semakin tinggi iman dan takwa seseorang semakin tinggi pula ke tiga Kapital di atas. Namun demikian banyak akademisi yang menyarankan agar kapital spiritual dipisahkan dari ketiga kapital of atas, dengan tujuan untuk semakin menekankan betapa pentingnya upaya pengembangan keberagamaan manusia.

Di mata para akademisi yang berpandangan demikian, agama akan menjadi pembimbing kehidupan agar tidak menjadi egoistik yang orientasinya hanya memikirkan kepentingan dirinya sendiri. Oleh karena itu upaya untuk mengembangkan keagamaan adalah bagian mutlak dan utama bagi tumbuhnya masyarakat yang makmur dan sejahtera serta aman dan damai.

\section{KENDALA YANG MENGHAMBAT TUMBUHNYA KAPITAL}

Upaya untuk menumbuhkan secara optimal keempat kapital di atas menghadapi kendala organisasi dan kendala birokrasi. Dari segi kendala organisasi banyak perguruan tinggi yang of dalam pengelolaan lembaga masih menganut paradig- ma lama, yaitu terkotak-kotak antar unit kerja, dengan gaya kepemimpinan yang menekankan pada hirarki, peraturan dan petunjukteknis dan petunjuk pelaksanaan. Organisasi dengan paradigma lama ini sangat mengganggu kecepatan organisasi dalam beradaptasi pada perubahan lingkungan. Banyak sumberdaya yang seharusnya dipakai bersama-sama menjadi tidak termanfaatkan secara optimal, efisien dan efektif. Sifat egoistik kotak organisasi yang melihat dirinya sebagai unit yang terpisah dari yang lainnya menjadi sumber pemborosan sumberdaya yang ada. Tidak adanya keinginan untuk meleburkan batas antar kotak organisasi akan memperlambat proses pengambilan keputusan. Kelambatan dalam pengambilan keputusan ini selanjutnya melemahkan semangat untuk menumbuhkan berbagai kapital di atas.

Kendala organisasi yang lain adalah masalah budaya pelayanan. Masih banyak tenaga pengajar dan karyawan yang bel um melihat mahasiswa sebagai pelanggan (customer). Bila mahasiswa dilayani seperti pelanggan, maka mahasiswa akan betah tinggal d kampus dan mendapat contoh panutan (role model) tentang bagaimana sikap peduli dan melayani orang lain. Banyaknya universitas yang mulai menerapkan prinsip kualitas (ISO 9000) dalam pengelolaan perguruan tinggi, Insya Allah akan menjadikan kendala tersebut akan hilang.

Kendala lain yang jauh lebih berat untuk mengatasinya adalah besarnya kekuasaan birokrasi atas pengelolaan perguruan tinggi. Adanya kurikulum nasional yang sangat kaku dan jarang diperbaharui membuat perguruan tinggi menjadi kurang adaptif terhadap perubahan yang ada di dalam masyarakat. Berbagai aturan yang diterapkan pada perguruan tinggi swasta terasa mernberatkan bagi mereka yang mernatuhinya. 
Kuatnya peranan birokrasi pada pendidikan tinggi seringkali membuat orangorang yang bekerja di perguruan tinggi sebagai sub-ordinasi birokrasi. Peraturan yang berlaku di lembaga birokrasi nonpendidikan diberlakukan pada perguruan tinggi. Kewenangan untuk membirnbing skripsi, tesis dan disertasi diatur oleh pangkat bukan oleh kemampuan intelektual seseorang. Pimpinan perguruan tinggi bukan dipilih dan ditetapkan oleh anggota senat univeritas, tetapi oleh birokrasi pengelola pendidikan tinggi di tingkat pusat. Banyak calon pimpinan PTN yang sudah dipilith oleh sernat, yang menurut pandangan senat cukup mampu untuk memimpin lembaga pendidikan, digusur oleh rezirn orde baru karena dinilai tidak sesuai dengan selera penguasa.

\section{PENUTUP}

Apakah milenium ketiga akan penuh dengan berkah atau malapetaka sangat tergántung kepada upaya manusia untuk mempersiapkan dirinya. Banyak hal yang harus dipersiapkan baik dari segi perangkat keras maupun perangkat lunak. Manusia sebagai perangkat lunak sudah selayaknyalah berbuat untuk mengembangkan ke empat kapital yang diuraikan di atas. Semoga perguruan tinggi yang berusaha keras untuk membangun perangkat lunak akan membawa kecerahan bagi ummat manusia. 0

\section{DAFTAR PUSTAKA}

Covey, S.R. 1988. Seven Habits of Highly Effipctive People: Powerful Lessons in Personal Change. New York: Simon \& Schuster.

Gibson, R 1997. Rethinking the Future. London: Nicholas Brealey Publishing.
Goleman, D. 1996. Emotional intelligence. New York: Bantam Books.

Hartanto, F.M. 1997. Virtual Capital, bahan presentasi Caltex Leadership Development Program II. Rumbai: LDS, PT. $\mathrm{CPI}$.

Hartanto, F.M; 1998. Raka, G \& Hendroyuwono, W. Percakapan tentang Virtual Kapital bersarna Djarnaludin Ancok, dalam Tean Caltex Ledership Deveopment Program, Yogyakarta.

Jarman, B. \& Land, G. 1995. Beyond Breakpoint: Possible for New Community. Dalam Gozdz, K (Ed.) Commurity Building. San Fransisco: Sterling \& Stone, Inc.

Kennedy, P. 1993. Preparing for the Twenty Fist Century. New York Random House.

Maynard, H.B. 1993. J. \& Mehrtens, S.E. The Fourth Wave: Business in the 21st Century. San Fransisco: Berret-Koehler Publishers.

Moore, J.F. 1996. The Death of Competition: Leadership \& Strategy in the Age of Business Ecosystems. New York: Harper Business.

Naisbitt, J. 1995. Megatrends for Asia. New York: Williarn Morrow and Company.

Ross, J. 1997. et.al. Intellectual capital: Navigating the New Business Landscape. New York: MacMillan.

Tapscott, D. 1996. Digital Economy: Promise and Peril in the Age of Networked Intelligence. New York McGraw-Hill.

Toffler, A 1990. The Power Shift Knowledge, Wealth, and Violence at the Edge of the 21st Century. New York: Bantam Books. 
Toffler, A. 1980. The Third Wave. New York Toffler, A. 1970. Fiture Schock. New York Bantam Books. Bantam Books.

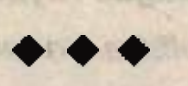

